\title{
TRANSMISI GEN krt-GP11 DAN PERFORMA KETAHANAN IKAN MAS (Cyprinus carpio) TRANSGENIK F-2 TERHADAP INFEKSI KHV
}

\author{
Khairul Syahputra*, Flandrianto Sih Palimirmo, dan Yogi Himawan \\ Balai Penelitian Pemuliaan Ikan
}

\begin{abstract}
ABSTRAK
Pembentukan ikan mas transgenik merupakan salah satu program penelitian di Balai Penelitian Pemuliaan Ikan, Sukamandi dalam rangka menghasilkan varietas unggul ikan mas tahan infeksi KHV (Koi herpesvirus). Pada tahun 2015 telah dilakukan pembentukan ikan mas transgenik tahan KHV generasi F-2. Penelitian ini bertujuan untuk mengevaluasi transmisi gen krt-GP11, ketahanan ikan mas transgenik F-2 terhadap infeksi $\mathrm{KHV}$, keberadaan marka Cyca-DAB1*05 tahan KHV pada populasi ikan mas transgenik F-2. Ikan mas transgenik F-2 dihasilkan dengan memijahkan ikan mas transgenik F-1 jantan dengan betina non-transgenik. Pengujian transmisi transgen dan deteksi marka ketahanan KHV pada transgenik F-2 dilakukan dengan metode PCR menggunakan primer spesifik untuk transgen krt-GP11 dan gen Cyca-DAB1*05. Evaluasi ketahanan ikan mas transgenik F-2 terhadap infeksi KHV dilakukan dengan uji tantang secara kohabitasi. Hasil penelitian menunjukkan bahwa transmisi gen krt-GP11 pada keturunan F-2 memiliki persentase yang relatif rendah yaitu sebesar $0 \% 2 \% \mathrm{Ikan}$ mas transgenik F-2 memiliki ketahanan relatif baik terhadap KHV dengan sintasan uji tantang sebesar $90 \%$ dan tidak berbeda nyata dengan ikan mas pembanding atau non-transgenik $(P>0,05)$. Tingginya pesentase keberadaan marka Cyca-DAB1*05 pada populasi transgenik berperan pada ketahanan ikan mas transgenik terhadap infeksi KHV.
\end{abstract}

KATA KUNCl: ikan mas; KHV; transgenik; uji tantang; transmisi gen krt-GP11

ABSTRACT: Transmission of krt-GP11 gene and resistance performance of F-2 transgenic common carp (Cryprinus carpio) against to KHV infection. By: Khairul Syahputra, Flandrianto Sih Palimirmo, and Yogi Himawan

Creating of transgenic common carp is one of the breeding programs in Research Institute for Fish Breeding for producing a superior strain of common carp resistant to KHV (Koi herpesvirus). Since 2015, the creation of common carp transgenic has been conducted to produce $\mathrm{F}_{2}$ population resistant to $\mathrm{KHV}$. This study was aimed to evaluate the transmission of krt-GP11 gen, the resistantce of $F_{2}$ transgenic common carp against to KHV infection, and the existence of Cyca-DAB1*05 marker resistant to $\mathrm{KHV}$ in $\mathrm{F}_{2}$ transgenic population. $\mathrm{F}_{2}$ transgenic population has been

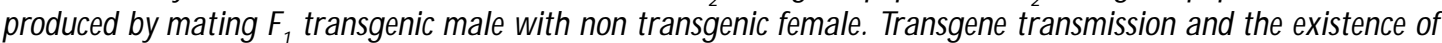
marker resistant to $\mathrm{KHV}$ in $\mathrm{F}_{2}$ transgenic population were evaluated by PCR method using specific primer to krt-GP11 gene and Cyca-DAB1*05 gene, respectively. The resistance of $F_{2}$ transgenic population againstto $\mathrm{KHV}$ infection was evaluated by challenge test using cohabitation method. The result showed that transmission of krt-GP11 gene in $F_{2}$ transgenic population was relatively low with percentage of $0-2 \%$ The resistance of $\mathrm{F}_{2}$ transgenic common carp against to $\mathrm{KHV}$ was relatively high with survival rate of $90 \%$ and was not significantly different from non transgenic $(\mathrm{P}>0.05)$. High percentage of transgenic population having Cyca-DAB1*05 marker had a role in resistance of transgenic population against KHV infection.

KEYWORDS: common carp; KHV; transgenic; challenge test; transgene transmission

\section{PENDAHULUAN}

Teknologi transgenik potensial digunakan untuk meningkatkan ketahanan penyakit pada ikan

\footnotetext{
\# Korespondensi: Balai Penelitian Pemuliaan Ikan. JI. Raya 2 Pantura Sukamandi, Subang 41263, Jawa Barat, Indonesia. Tel. + (0260) 520500

E-mail: khairul_syahputra@yahoo.com
}

khususnya pada ikan budidaya yang bernilai ekonomis tinggi (Zhong et al., 2002; Dunham, 2009). Pemanfaatan teknologi ini telah diawali oleh Anderson et al. (1996) dengan mentransfer gen penyandi antisense viral (viral coat protein gene) yang dapat meningkatkan ketahanan ikan rainbow trout (Oncorhynchus mykiss) terhadap virus. Peningkatan ketahanan penyakit dengan transgenesis juga telah dilakukan untuk 
penyakit lainnya seperti introduksi gen laktoferin pada ikan grass carp (Ctenopharyngodon idellus) yang dapat meningkatkan ketahanan terhadap virus GCH (Grass Carp Haemorrhage) (Zhong et al., 2002), sedangkan pada udang telah dilakukan oleh Lu \& Sun (2005) dengan mentransfer gen antisense Taura syndrome virus-coat protein dapat meningkatkan ketahanan terhadap virus Taura. Tidak hanya ketahanan terhadap virus, ketahanan penyakit yang disebabkan bakteri juga telah dilaporkan, seperti pada ikan channel catfish (Ictalurus punctatus) (Dunham et al., 2002), ikan medaka (Sarmasik et al., 2002), dan ikan grass carp (Weifeng et al., 2004). Ketahanan terhadap bakteri dan virus juga telah dilaporkan oleh Chiou et al. (2014) pada ikan rainbow trout.

Pendekatan transgenesis perlu dilakukan untuk menghasilkan ikan mas tahan penyakit khususnya Koi Herpesvirus (KHV). KHV merupakan virus yang menyerang dan menyebabkan kematian massal pada ikan mas, penyakit KHV menyebabkan penurunan produktivitas nasional ikan mas sejak tahun 2002 (Sunarto et al., 2005). Pembentukan ikan mas tahan KHV dapat dilakukan dengan mentransfer gen imunogenik (glikoprotein) tahan KHV. Beberapa hasil penelitian menyebutkan bahwa gen glikoprotein dapat meningkatkan ketahanan ikan terhadap virus seperti pada ikan rainbow trout (LaPatra et al., 2001; Kim et al., 2000), ikan mas (Kanellos et al., 2006), dan ikan koi (Emmenegger \& Kurath, 2008).

Pembentukan ikan mas transgenik tahan KHV telah diawali dengan pembentukan ikan mas transgenik founder dengan mengintroduksikan gen glikoprotein tahan KHV (krt-GP11) menggunakan metode elektroporasi sperma. Pada tahun 2013 telah diperoleh calon induk founder jantan yang positif membawa transgen di sperma, dan pada tahun 2014 telah diperoleh ikan mas transgenik F-1 jantan yang positif membawa transgen di sperma. Berdasarkan hasil uji tantang, ikan mas transgenik F-1 memiliki daya tahan terhadap KHV yang lebih baik dibandingkan ikan nontransgenik dengan peningkatan sintasan sebesar 20,32\% (Syahputra et al., 2014). Pada tahun 2015, kegiatan penelitian lanjutan yang dilakukan adalah pembentukan ikan mas transgenik F-2 tahan KHV. Pembentukan ikan mas transgenik $\mathrm{F}-2$ dilakukan dengan mengawinkan ikan mas jantan transgenik F-1 dengan ikan mas betina non-trangenik.

Penelitian ini bertujuan untuk mengevaluasi transmisi gen krt-GP11 pada ikan mas transgenik generasi F-2 dan mengevaluasi performa ketahanannya terhadap KHV. Selain itu, pada penelitian ini juga dilakukan evaluasi keberadaan marka molekuler CycaDAB1*05 terkait ketahanan KHV pada populasi ikan mas transgenik F-2. Keberadaan marka tersebut dapat memengaruhi ketahanan ikan mas transgenik F-2 terhadap infeksi KHV selain gen krt-GP11 yang telah diintroduksikan. Beberapa penelitian terbaru menunjukkan bahwa marka Cyca-DAB1*05 berkorelasi terhadap ketahanan ikan mas terhadap infeksi KHV seperti yang dilaporkan oleh Rakus et al. (2009) dan Alimuddin et al. (2011), dan bahkan marka ini telah berhasil dan efektif digunakan pada kegiatan pemuliaan ikan mas tahan KHV di Indonesia (Ariyanto et al., 2015; Sucipto et al., 2014).

\section{BAHAN DAN METODE}

\section{Pembentukan Populasi F-2 Transgenik}

Sebanyak lima ekor induk jantan F-1 transgenik yang membawa gen krt-GP11 pada gamet dipijahkan dengan induk betina yang non-transgenik untuk mendapatkan keturunan F-2. Induk yang telah matang gonad dipijahkan dan ditempatkan ke dalam bak pemijahan. Pemijahan dilakukan dengan metode semibuatan dan buatan yang disesuaikan dengan kondisi kesiapan induk saat pemijahan. Induk diinduksi dengan penyuntikan ovaprim untuk mendapatkan keseragaman kematangan sperma, telur, dan ovulasi. Pada induk betina ovaprim diberikan dengan dosis $0,3 \mathrm{~mL} / \mathrm{kg}$ bobot, sedangkan pada induk jantan dilakukan penyuntikan ovaprim dengan dosis $0,15 \mathrm{~mL} /$ $\mathrm{kg}$ bo bot. Pada pemijahan buatan, sel telur, dan sperma diperoleh dari induk yang telah diinjeksi ovaprim dengan cara striping yang dilakukan 10-12 jam setelah penyuntikan. Larva dan benih yang dihasilkan dipelihara sesuai dengan SOP pemeliharaan larva dan benih ikan mas. Larva dipelihara pada bak pendederan tahap-1 ukuran $25 \mathrm{~m}^{2}$ dengan kepadatan $800 \mathrm{ekor} / \mathrm{m}^{2}$. Selama pemeliharaan, larva memanfaatkan pakan alami yang terdapat pada bak pemeliharaan yang telah disiapkan sebelumnya. Setelah dua minggu dalam tahap pemeliharaan pendederan-1, benih dipindahkan ke bak pendederan tahap-2 dengan kepadatan 50 ekor $/ \mathrm{m}^{2}$. Selama tahap pendederan-2 benih diberi pakan buatan dengan kandungan protein 40\%sampai umur 2-3 bulan.

\section{Transmisi Transgen}

Transmisi transgen pada keturunanan F-2 dilakukan dengan analisis PCR menggunakan DNA genom dari larva dan benih ikan mas transgenik yang telah berumur 2-3 bulan. Pada larva, deteksi transgen dilakukan pada 150 ekor larva yang telah berumur tiga hari setelah menetas dan diambil secara acak pada setiap populasi F-2. Ekstraksi DNA genom larva dilakukan dengan cara digabung (pool), setiap pool berisi sebanyak 30 larva. Berbeda dengan larva, deteksi transgen pada benih dilakukan secara individu 
menggunakan DNA genom yang diekstraksi dari jaringan sirip. Deteksi dilakukan pada 100 ekor benih ikan mas trasngenik F-2 yang telah berumur 2-3 bulan yang diambil secara acak. Ekstraksi DNA genom dilakukan dengan menggunakan kit komersial GeneJET DNA Purification Kit (Thermo Scientific, Lithuania), dengan prosedur mengikuti protokol yang terdapat pada manual kit. DNA hasil ekstraksi disimpan pada suhu $-20^{\circ} \mathrm{C}$ hingga dilakukan proses amplifikasi PCR. Kemurnian dan kuantitas DNA diukur menggunakan alat GeneQuant ${ }^{\mathrm{TM}} 1300$.

Analisis PCR untuk deteksi transgen dilakukan menggunakan kit FastStart PCR Master (Roche, Jerman) dan primer spesifik untuk gen krt-GP11 yaitu forward: 5'-GCCTTCGTGGCCCTTCCCAC-3' dan reverse: 5'-GGTTGCTCCTGTCCGCCACC-3' dengan panjang fragmen amplifikasi 480 bp. Komposisi bahan yang digunakan untuk amplifikasi PCR adalah $12,5 \mu \mathrm{L}$ Master Mix PCR; 0,375 $\mu \mathrm{L}$ untuk tiap primer $(20 \mu \mathrm{M}) ; 2,5$ $\mu \mathrm{L}$ DNA genom dan ditambahkan water PCR-grade hingga total volume $25 \mu \mathrm{L}$. Program PCR yang digunakan meliputi: $95^{\circ} \mathrm{C}$ selama empat menit; $\left(95^{\circ} \mathrm{C}\right.$ selama 30 detik; $64^{\circ} \mathrm{C}$ selama 30 detik; $72^{\circ} \mathrm{C}$ selama satu menit) sebanyak 40 siklus; dan $72^{\circ} \mathrm{C}$ selama tujuh menit. Hasil amplifikasi PCR diseparasi dengan elektroforesis pada gel agarose $2 \%$ yang telah diberi pewarna GelRed ${ }^{\mathrm{TM}}$ (Biotium) dan hasil elektroforesis diamati pada UV transiluminator dan didokumentasikan menggunakan kamera digital Canon EOS 1100D.

\section{Deteksi Marka Cyca-DAB1*05 pada Populasi Ikan Mas Transgenik F-2}

Pengujian ini dilakukan untuk mengevaluasi pengaruh keberadaan marka Cyca-DAB1*05 terhadap ketahanan ikan mas transgenik F-2 pada infeksi KHV selain peran transgen krt-GP11 yang telah diintroduksi. Deteksi marka Cyca-DAB1*05 dilakukan pada 50 ekor ikan mas transgenik F-2 dengan metode PCR menggunakan primer spesifik untuk alel CycaDAB1*05 (Alimuddin et al., 2011) yaitu forward: CTAATGGATACTACTGG dan reverse: ATCGCTGACTGTCTGTT dengan ukuran produk amplifikasi sebesar 300 bp. Marka Cyca-DAB1*05 dideteksi pada DNA genom yang diekstraksi dari jaringan sirip menggunakan kit komersial GeneJET DNA Purification Kit (Thermo Scientific, Lithuania), dengan prosedur mengikuti protokol yang terdapat pada manual kit. Program PCR amplifikasi Cyca-DAB1*05 meliputi: $95^{\circ} \mathrm{C}$ selama tiga menit; $\left(95^{\circ} \mathrm{C}\right.$ selama 30 detik; $50^{\circ} \mathrm{C}$ selama 30 detik; $72^{\circ} \mathrm{C}$ selama satu menit) sebanyak 30 siklus; dan $72^{\circ} \mathrm{C}$ selama 10 menit. Hasil amplifikasi PCR marka Cyca-DAB1*05 divisualisasi dengan prosedur yang telah dijelaskan sebelumnya.

\section{Uji Tantang Ikan Mas Transgenik F-2}

Uji tantang dilakukan dengan metode kohabitasi yang mengacu pada protokol nomor-3 tentang uji tantang ikan mas terhadap KHV (Pusat Pengembangan Ikan Mas Nasional, PPIMN 2012). Ikan uji yang digunakan adalah benih ikan mas transgenik $F-2$ yang diambil secara acak pada populasi $F_{2} B \# 2$. Populasi $\mathrm{F}_{2} \mathrm{~B} \# 2$ merupakan populasi terindikasi positif membawa gen krt-GP11 di benih. Sebagai pembanding digunakan ikan mas Rajadanu hasil seleksi tahan KHV yang merupakan koleksi BPPI, Sukamandi dan ikan mas Majalaya tahan KHV (Mantap) yang diperoleh dari BBPAT, Sukabumi. Pengujian dilakukan dengan menambahkan sebanyak tiga ekor ikan sumber infeksi KHV pada tiap pengujian. Ikan sumber infeksi KHV dibuat dengan cara menginjeksikan filtratehomogenate virus KHV dengan dosis 0,1 mL/ekor. Setelah diinjeksi virus KHV, ikan sumber dipelihara dalam akuarium berukuran $60 \mathrm{~cm} \times 40 \mathrm{~cm} \times 40 \mathrm{~cm}$ dengan kepadatan satu ekor per liter air hingga menunjukkan gejala klinis terinfeksi KHV. Verifikasi ikan sumber telah terinfeksi KHV dilakukan dengan metode PCR. Analisis PCR dilakukan pada beberapa ikan sumber yang menunjukkan gejala klinis terinfeksi KHV selama pemeliharaan.

Uji tantang dilakukan pada wadah uji berupa akuarium berukuran $60 \mathrm{~cm} \times 40 \mathrm{~cm} \times 40 \mathrm{~cm}$. Jumlah ikan uji yang digunakan sebanyak 30 ekor per akuarium dengan kepadatan satu ekor per liter air. Setiap perlakuan uji tantang dilakukan dengan tiga kali ulangan. Suhu air pemeliharaan dikondisikan pada suhu yang permisif bagi perkembangan KHV yaitu berkisar $22^{\circ} \mathrm{C}-24^{\circ} \mathrm{C}$. Uji tantang dilakukan selama 14 hari, setiap akuarium pengujian diberikan aerasi yang cukup selama pengujian. Ikan uji diberi pakan dua kali sehari menggunakan pakan komersial (protein 28\%. Pakan diberikan secukupnya agar ikan uji tetap bertahan hidup. Penyifonan dan pergantian air (sebanyak $50 \%$ volume air pengujian) dilakukan setiap dua hari sekali untuk membersihkan sisa pakan. Pengamatan gejala klinis dan mortalitas ikan uji dilakukan setiap hari selama pengujian. Ikan yang mati selama pengujian dan selanjutnya dilakukan pemeriksaan KHV menggunakan metode PCR.

\section{Pemeriksaan KHV dengan Metode PCR}

Pemeriksaan KHV pada ikan uji dilakukan menggunakan DNA genom yang diekstraksi dari organ insang. DNA genom diekstraksi menggunakan kit komersil DNAzol Reagent Genomic DNA Isolation Reagent (MRC, USA) sesuai prosedur yang terdapat pada manual kit. DNA genom hasil ekstraksi diamplifikasi menggunakan kit PCR Hot Start Green PCR master Mix 
2X (Thermo Scientific, Lithuania). Primer PCR yang digunakan untuk pemeriksaan KHV adalah sphl-5 dengan sekuen forward 5'-GAC ACC ACA TCT GCA AGG AG-3' dan reverse 5'-GAC ACA TGT TAC AAT GGT CGC3' dengan panjang fragmen amplifikasi $290 \mathrm{bp}$. Komposisi bahan yang digunakan untuk amplifikasi PCR adalah 12,5 $\mu \mathrm{L}$ Maxima Hot Start Green PCR Master M ix (2X); 0,5 $\mu$ L untuk tiap primer $(20 \mu \mathrm{M}) ; 2 \mu \mathrm{L}$ DNA genom dan ditambahkan water nuclease-freehingga total volume $25 \mu \mathrm{L}$. Proses PCR dilakukan dengan program: $95^{\circ} \mathrm{C}$ selama empat menit; $\left(95^{\circ} \mathrm{C}\right.$ selama 30 detik; $55^{\circ} \mathrm{C}$ selama 30 detik; $72^{\circ} \mathrm{C}$ selama satu menit) sebanyak 40 siklus; dan $72^{\circ} \mathrm{C}$ selama 10 menit. Hasil amplifikasi PCR dicek dengan prosedur yang telah dijelaskan sebelumnya.

\section{Analisa Data}

Data transmisi gen krt-GP11 dan pemeriksaan marka Cyca-DAB1*05 pada populasi transgenik F-2, serta data hasil deteksi KHV pada uji tantang dianal isis secara deskriptif. Analisis statistik dilakukan pada data sintasan uji tantang menggunakan uji one way Anova dengan selang kepercayaan $95 \%$

\section{HASIL DAN BAHASAN}

\section{Populasi Ikan Mas Transgenik F-2}

Sebanyak lima populasi ikan mas transgenik F-2 heterozigot telah dibentuk pada penelitian ini yaitu populasi $\mathrm{F}_{2} \mathrm{SA} \# 1, \mathrm{~F}_{2} \mathrm{SA} \# 2, \mathrm{~F}_{2} \mathrm{SA} \# 3, \mathrm{~F}_{2} \mathrm{~B} \# 1$, dan $\mathrm{F}_{2} \mathrm{~B} \# 2$. Populasi $\mathrm{F}_{2} \mathrm{SA \#} 1, \mathrm{~F}_{2} \mathrm{SA \# 2}$, dan $\mathrm{F}_{2} \mathrm{SA \#} 3$ dihasilkan dari pemijahan semi-buatan sedangkan $\mathrm{F}_{2} \mathrm{~B} \# 1$ dan $\mathrm{F}_{2} \mathrm{~B} \# 2$ dihasilkan dari pemijahan buatan.

\section{Deteksi dan Transmisi Gen krt-GP11 Pada Larva dan Benih Populasi F-2 Transgenik}

Hasil analisis PCR deteksi transgen krt-GP11 pada larva menunjukkan bahwa hanya satu populasi yang positif membawa transgen di larva dari lima populasi yang dihasilkan, yaitu populasi $\mathrm{F}_{2} \mathrm{SA \#} 1$. Transgen yang terdeteksi pada populasi $\mathrm{F}_{2} \mathrm{SA \#} 1$ menunjukkan persentase yang kecil, dari lima sampel pengujian dengan masing-masing sampel terdiri atas 30 ekor Iarva hanya satu sampel yang positif terdeteksi transgen untuk masing-masing populasi (Gambar 1).

Hasil yang relatif berbeda terdeteksi pada level benih, berdasarkan analisis PCR menunjukkan bahwa pada populasi $\mathrm{F}_{2} \mathrm{~B} \# 2$ yang negatif transgen di larva namun terdeteksi pada level benih. Hal ini disebabkan karena transmisi transgen yang relatif rendah, sehingga individu transgenik yang terdistribusi pada populasi transgenik memiliki persentase yang kecil. Selain itu, pengambilan sampel yang dilakukan secara acak memungkinkan transgenik hanya terdeteksi pada benih bukan pada larva dan juga sebaliknya dapat terdeteksi hanya pada larva tapi tidak terdeteksi di benih kerena individu yang diperiksa dalam populasi berbeda. Sementara itu, hasil yang konsisten ditunjukkan pada populasi $F_{2} B \# 1, F_{2} S A \# 2$, dan

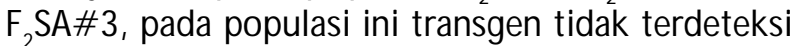
baik pada tahap larva maupun benih. Sampel benih yang diperiksa untuk tiap populasi adalah sebanyak 100 ekor. Transgen yang terdeteksi pada populasi benih $\mathrm{F}_{2} \mathrm{~B} \# 2$ memiliki persentase yang kecil yaitu dari 100 ekor yang diperiksa hanya dua ekor yang positif transgen (Gambar 2).

Hasil deteksi transgen pada larva dan benih ikan mas transgenik F-2 menunjukkan bahwa transgen dapat diwariskan atau ditransmisikan dari F-1 pada generasi F-2, meskipun tidak semua induk F-1 dapat menurunkan transgen pada F-2. Transmisi transgen dari F-1 ke F-2 lebih rendah dibandingkan dengan generasi sebelumnya yaitu dari founder ke F-1. Transmisi transgen pada penelitian ini hanya $2 \%$ sedangkan dari founder ke F-1 sebesar 3\%(Syahputra et al., 2014). Transmisi transgen pada penelitian juga berbeda dengan transmisi transgen pada ikan mas transgenik yang dilaporkan oleh Zhong et al. (2012) ikan mas transgenik yang ditransfer gen hormon petumbuhan menggunakan metode mikroinjeksi memiliki transmisi transgen yang mengikuti pola pewarisan Mendel.

Transmisi transgen pada ikan mas transgenik pada penelitian ini juga cukup rendah dibandingkan dengan penelitian transgenik pada ikan lainnya. Pada ikan transgenik coho salmon, transmisi transgen dari founder ke F-1 bervariasi dengan kisaran transmisi 2,2\%18,9\% (Devlin et al., 1995). Devlin et al. (1995) juga melaporkan bahwa sebanyak lima ekor induk jantan founder tidak mentransmisikan transgen pada keturunan F-1. Variasi transmisi transgen pada ikan transgenik juga dilaporkan oleh Kobayashi et al. (2007), transmisi trangen dari induk F-1 ikan nila transgenik pada keturunan $\mathrm{F}-2$ berkisar antara $55 \% 60 \%$

Rendahnya transmisi transgen pada ikan mas transgenik F-2 kemungkinan disebabkan karena transgen yang terintroduksi pada induk transgenik F-1 memiliki jumlah kopi yang sedikit, terdistribusi mosaik pada jaringan termasuk sel gonad, dan tidak terintegrasi pada genom. Maclean (1998) menyatakan bahwa transgen akan sulit atau tidak mungkin ditransmisikan pada generasi berikutnya jika sel-sel germinal ikan transgenik hanya membawa sedikit dan atau bahkan tidak membawa transgen. Ikan transgenik yang tidak mentransmisikan transgen pada keturunannya mengindikasikan bahwa transgen tidak terintegrasi pada sel-sel germinal. Secara teori, jika semua sel-sel germinal ikan transgenik membawa 


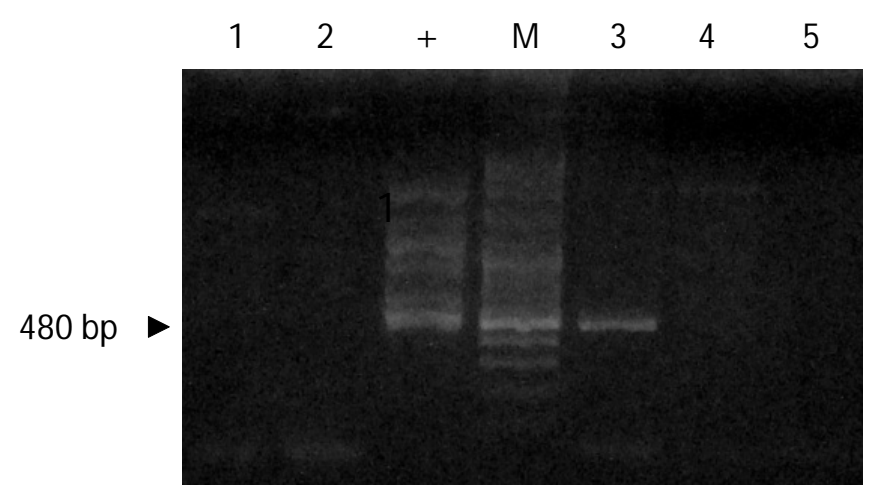

Gambar 1. Deteksi transgen (krt-GP11) pada lima populasi larva ikan mas transgenik $F_{2}$; $\mathrm{M}=$ marker DNA; $(+)=$ kontrol positif plasmid; $1=\mathrm{F}_{2} \mathrm{~B} \# 1 ; 2=\mathrm{F}_{2} \mathrm{~B} \# 2 ; 3=$ $\mathrm{F}_{2} \mathrm{SA \#} 1 ; 4=\mathrm{F}_{2} \mathrm{SA \# 2}$; dan $5=\mathrm{F}_{2} \mathrm{SA \#} 1$

Figure 1. Detection of transgene (krt-GP11) in five larvae of populations F-2 transgenic common carp; $M=$ DNA marker; $(+)=$ positive control of plasmid; $1=F_{2} B \# 1 ; 2=$ $F_{2} B \# 2 ; 3=F_{2} S A \# 1 ; 4=F_{2} S A \# 2 ;$ and $5=F_{2} S A \# 1$

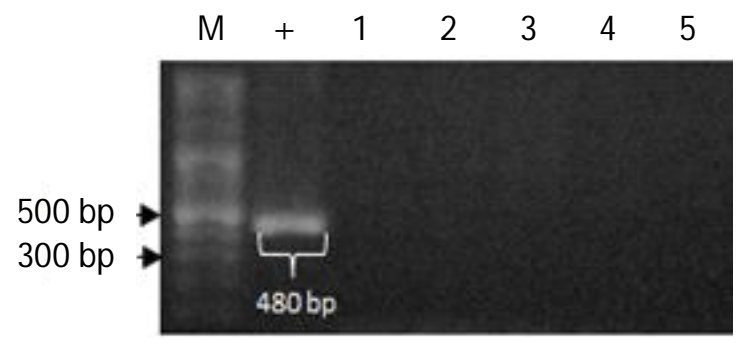

A

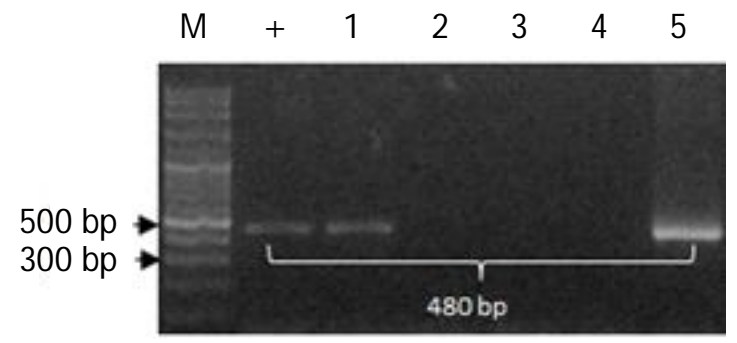

B

Gambar 2. Deteksi transgen (krt-GP11) pada benih ikan mas transgenik $F-2 ; A$ ) populasi $F_{2} B \# 1$ dan $\mathrm{B})$ populasi $\mathrm{F}_{2} \mathrm{~B} \# 2$; $\mathrm{M}=$ marker $\mathrm{DNA} ;(+)=$ kontrol positif plasmid; $1-5=$ sampel benih ikan mas transgenik $\mathrm{F}-2$

Figure 2. Detection of transgene (krt-GP11) of juvenile F-2 transgenic common carp; A) $F_{2} B \# 1$ population and $B) F_{2} B \# 2$ population; $M=$ DNA marker; $(+)=$ positive control of plasmid; $1-5=$ juvenile samples of $\mathrm{F}-2$ transgenic common carp

transgen (tidak terdistribusi mosaik) dan ikan tersebut dikawinkan dengan non-transgenik akan menghasilkan $50 \%$ anakan transgenik (Figueiredo et al., 2007). Maclean (1998) menambahkan bahwa identifikasi ikan transgenik akan sulit dilakukan pada populasi dengan persentase transgenik yang relatif kecil dan terdistribusi mosaik, kecuali pada populasi tersebut menggunakan penanda yang mudah dideteksi seperti genereporter.

\section{Uji Tantang}

Berdasarkan hasil uji tantang, ikan mas transgenik F-2 memiliki ketahanan terhadap KHV yang relatif tinggi meskipun tidak lebih baik dibandingkan dengan ikan pembanding atau non-transgenik. Secara statistik, tingkat ketahanan ikan mas transgenik F-2 terhadap KHV tidak berbeda signifikan dengan ikan pembanding
$(P>0,05)$. Ikan pembanding merupakan ikan mas Rajadanu dan Majalaya yang membawa marka CycaDAB1*05 terkait ketahanan terhadap infeksi KHV (Ariyanto et al., 2015). Ikan mas transgenik F-2 yang ditantang dengan KHV selama 14 hari memiliki sintasan 90\% Performa ketahanan KHV ikan mas transgenik F-2 lebih baik dibandingkan dengan $F_{1}$ dan sedikit lebih rendah dibandingkan dengan generasi founder. Berdasarkan uji tantang dengan metode dan kondisi yang relatif sama, ikan mas transgenik F-1 memiliki sintasan sebesar 85,56\%dan founder memiliki sintasan sebesar 98,89\%(Gambar 3).

Hasil penelitian ini menunjukkan bahwa selain transgen dapat diwariskan, performa ketahanan ikan mas transgenik terhadap KHV juga diwariskan dari F-1 ke generasi F-2. Beberapa hasil penelitian lain menyebutkan bahwa karakter ketahanan penyakit pada 

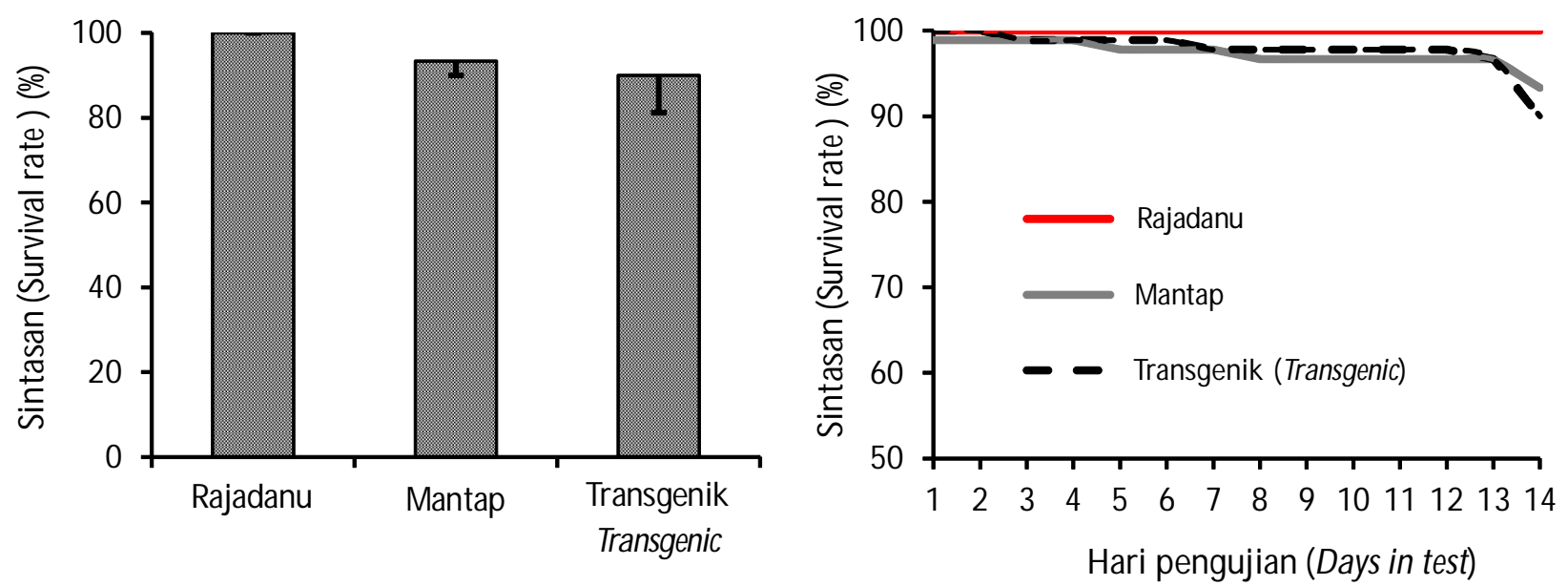

Gambar 3. Sintasan (A) dan sintasan harian kumulatif (B) ikan uji hasil uji tantang dengan KHV. Sintasan ikan uji tidak berbeda secara signifikan $(P>0,05)$ (Bar merupakan standar deviasi $(n=3)$

Figure 3. Survival rate (A) and cumulative daily survival rate (B) of test fish after $\mathrm{KHV}$ challenge test. Survival rates of test fish were not significantly different $(P>0.05)$ (Bars are standard deviation $(n=3))$

ikan transgenik dapat diwariskan pada generasi berikutnya. Chiou et al. (2014) melaporkan bahwa pada ikan transgenik rainbow trout tetap memiliki ketahanan terhadap infeksi IHNV dan Aeromonas sp. pada generasi F-2 dan F-3 (Chiou et al., 2014). Penelitian lainnya juga dilaporkan oleh Sarmasik et al. (2002), ikan medaka transgenik pada generasi F-2 memiliki resistensi terhadap infeksi bakteri Pseudomonas dan Vibrio.

Selain transgen krt-GP11, keberadaan marka CycaDAB $1 * 5$ juga berperan pada ketahanan ikan mas transgenik F-2 terhadap infeksi KHV selama uji tantang. Hasil uji PCR menunjukkan bahwa 92\%(46/ 50) dari populasi ikan mas transgenik F-2 positif membawa marka Cyca-DAB1*05 (Gambar 4). Rakus et al. (2009) dan Alimuddin et al. (2011) menyatakan bahwa marka Cyca-DAB1*05 merupakan marka molekuler ketahanan terhadap penyakit KHV pada ikan mas. Persentase keberadaan marka Cyca-DAB1*05 yang tinggi pada populasi ikan mas berkorelasi dengan ketahanan terhadap infeksi KHV. Sucipto et al. (2014) melaporkan bahwa 83,33\%populasi ikan mas Majalaya tahan KHV (M ANTAP) membawa marka Cyca-DAB1*05 dan memiliki sintasan uji tantang yang tinggi yaitu $100 \%$ Ariyanto et al. (2015) menambahkan, populasi ikan mas Rajadanu tahan infeksi KHV yang $100 \%$ membawa marka tersebut memiliki sintasan uji tantang sebesar $95 \%$

Berdasarkan hasil pemeriksaan KHV pada ikan uji yang mati setelah uji tantang menunjukkan bahwa kematian ikan uji selama uji tantang disebabkan oleh infeksi KHV. Semua ikan uji positif terinfeksi KHV berdasarkan analisis PCR (Gambar 5). Hasil pengujian ini juga menunjukkan bahwa ikan uji yang mampu

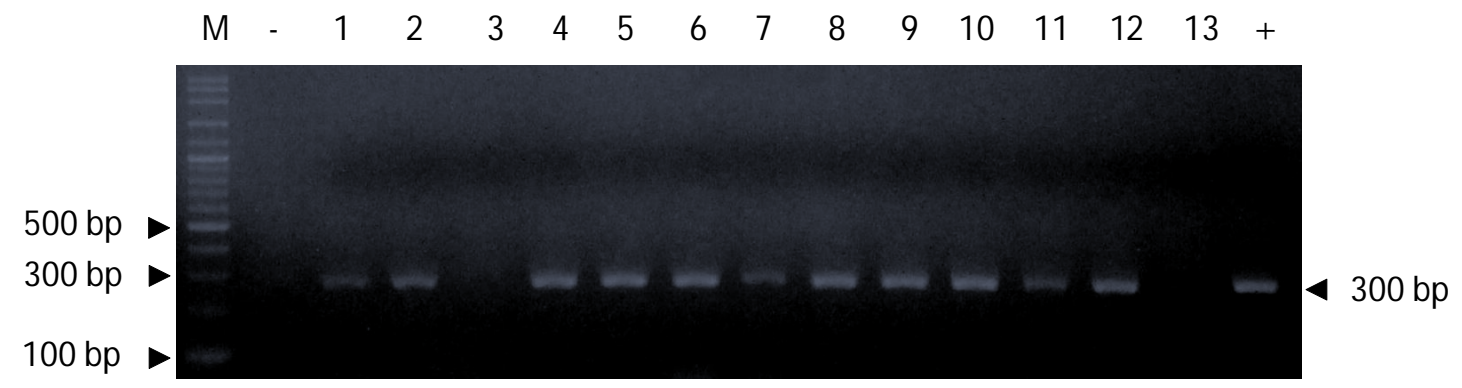

Gambar 4. Deteksi marka Cyca-DAB1 $* 05$ pada ikan mas transgenik F-2; $M=$ marker DNA; $(+)=$ kontrol positif marka Cyca-DAB1*05; (-)= kontrol negatif; 1-13= sampel ikan mas transgenik $\mathrm{F}-2$

Figure 4. Detection of Cyca-DAB1 $* 05$ marker in $\mathrm{F}-2$ transgenic common carp; $\mathrm{M}=\mathrm{DNA}$ marker; $(+)=$ positive control of Cyca-DAB1 $* 5$ marker; $(-)=$ negative control; $1-13=$ sample of $F-2$ transgenic common carp 


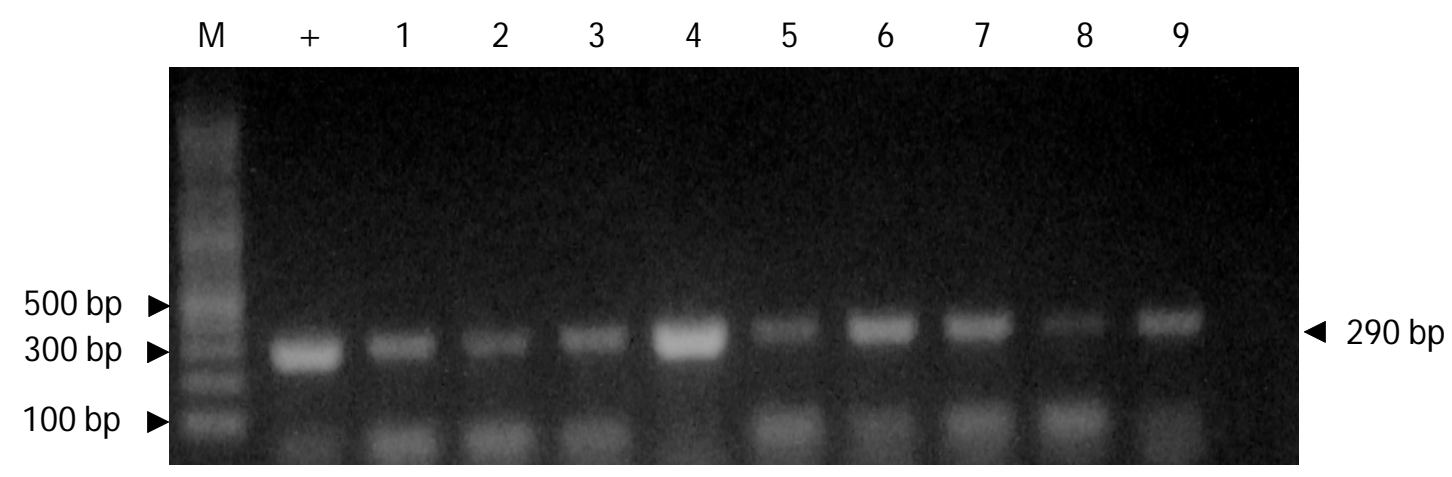

Gambar 5. Deteksi KHV pada ikan mas transgenik F-2 dan non-transgenik (Majalaya) yang mati setelah uji tantang KHV; $M=$ marker DNA; $(+)=$ kontrol positif KHV; $(-)=$ kontrol negatif; 1-4= transgenik; 5-9= non-transgenik

Figure 5. KHV detection in dead fish of F-2 transgenic common carp and non-transgenic (Majalaya) after KHV challenge test; $M=$ DNA marker; $(+)=$ positive control of $\mathrm{KHV} ;(-)=$ negative control; $1-4=$ transgenic; 5-9= non-transgenic

bertahan hidup merupakan ikan mas yang memiliki ketahanan terhadap infeksi KHV.

Parameter lain yang mendukung pada uji tantang KHV juga diamati pada penelitian ini meliputi gejala klinis dan suhu air pengujian. Berdasarkan pengamatan gejala klinis pada ikan uji selama uji tantang, ikan uji yang positif KHV dari hasil analisis PCR menunjukkan gejala klinis ikan mas terinfeksi KHV. Gejala klinis yang teramati pada ikan sakit dan mati meliputi respons ikan uji terhadap pakan berkurang, ikan lemah, dan gerakan lamban, dapat bergerak sangat aktif, sering naik ke permukaan air, insang pucat memutih dengan banyak lendir, kulit memar, dan melepuh. Gejala klinis yang teramati pada penelitian ini sama seperti yang dilaporkan oleh Gray et al. (2002), Sano et al. (2005), dan Sunarto et al. (2005).

Suhu air yang terukur selama pengujian berada pada kisaran yang permisif bagi perkembangan KHV yaitu berkisar antara $20^{\circ} \mathrm{C}-22^{\circ} \mathrm{C}$. Hedrick et al. (2000), Haenen et al. (2004), dan Sano et al. (2004) melaporkan bahwa suhu optimal perkembangan KHV yang menyebabkan kematian pada ikan mas berkisar antara $16^{\circ} \mathrm{C}-25^{\circ} \mathrm{C}$. Gillad et al. (2003) menambahkan bahwa $\mathrm{KHV}$ dapat tumbuh pada kisaran suhu $15^{\circ} \mathrm{C}-25^{\circ} \mathrm{C}$, suhu optimal bagi perkembangan KHV pada kisaran suhu $20^{\circ} \mathrm{C}-25^{\circ} \mathrm{C}$ yang menyebabkan kematian atau mortalitas pada ikan mas hingga $90 \% 95 \%$

\section{KESIMPULAN}

Transmisi gen krt-GP11 pada ikan mas transgenik keturunan F-2 relatif rendah yaitu berkisar $0 \% 2 \%$ Ikan mas transgenik F-2 memiliki ketahanan terhadap infeksi KHV yang relatif tinggi dengan sintasan uji tantang sebesar $90 \%$ Keberadaan marka Cyca-DAB1*05 berperan terhadap ketahanan ikan mas transgenik terhadap infeksi KHV selain transgen yang dintroduksikan.

\section{UCAPAN TERIMA KASIH}

Penelitian ini dibiayai oleh Anggaran Pendapatan dan Belanja Negara (APBN) melalui DIPA Tahun Anggaran 2015 di Balai Penelitian Pemuliaan Ikan, Sukamandi. Terima kasih disampaikan kepada semua teknisi yang telah membantu dalam kegiatan penelitian ini. Terima kasih juga disampaikan kepada dewan redaksi untuk semua saran, masukan, dan perbaikan terhadap makalah ini.

\section{DAFTAR ACUAN}

Alimuddin, Mubinun, Santika, A., Charman, O., Faizal, I., \& Sumantadinata, K. (2011). Identification of Majalaya common carp strains resistant to KHV infection using Cyca-DAB1*05 allele as the marker. Indonesian Aquaculture Journal, 6(2), 157-163.

Anderson, E.D., Mourich, D.V., \& Leong, J.C. (1996). Genetic immunization of rainbow trout (Oncorhynchus mykiss) against infectious hematopoietic necrosis virus. Mol. Mar. Biol. Biotechnol., 5, 114-22.

Ariyanto, D., Syahputra K., \& Himawan, Y. (2015). Naskah akademik pelepasan varietas unggul ikan mas Rajadanu tahan penyakit koi herpesvirus (KHV). Balai Penelitian Pemuliaan Ikan. Sukamandi, $90 \mathrm{hlm}$ (Unpublish).

Chiou, P.P., Chen, M.J., Lin, Chun-Mean., Khoo, J., Larson, J., Holt, R., Leong, Jo-Ann., Thorgarrd, 
G., \& Chen, T.T. (2014). Production of homozygous transgenic rainbow trout with enhanced disease resistance. Mar. Biotechnol., 16, 299-308.

Devlin, R.H., Yesaki, T.Y., Donaldson, E.M., \& Hew, Choy-Leong. (1995). Transmission and phenotypic effects of an antifreeze/GH gene construct in coho salmon (Onchorhynchus kisutch). Aquaculture, 137, 161-169.

Dunham, R.A., Warr, G., Nichols, A., Duncan, P.L., Argue, B., \& Middleton, D. (2002). Enhanced bacterial disease resistance of transgenic channel catûsh (Ictalarus punctatus), possessing cecropin genes. Mar. Biotechnol., 4, 338-344.

Dunham, R.A. (2009). Transgenic fish resistant to infectious diseases, their risk and prevention of escape into the environment and future candidate genes for disease transgene manipulation. Comparative Immunology, Microbiology and Infectious Diseases, 2, 139-161.

Emmenegger, E.J., \& Kurath, G. (2008). DNA vaccine protects ornamental koi (Cyprinus carpio koi) against North American spring viremia of carp virus. Vaccine, 26, 6415-6421.

Figueiredo, M.de.A., Lanes, C.F.C., Almeida, D.V., \& Marins, L.F. (2007). Improving the production of transgenic fish germlines: In vivo evaluation of mosaicism in zebrafish (Danio rerio) using a green fluoresncent protein (GFP) and growth hormone CDNA transgene co-injection strategy. Genetic and M olecular Biology, 30(1), 31-36.

Gillad, O., Yun, S., Adkison, M.A., Way, K., Willits, N.H., Bercovier, H., \& Hedrick, R.P. (2003). Molecular comparison of isolates of an emerging fish pathogen, koi herpesvirus, and the effect of water temperature on mortality of experimentally infected koi. Journal of General Virology, 84, 26612668.

Gray, W.L., Mullis, L., LaPatra S.E., Groff, J.M., \& Goodwin, A. (2002). Detection of koi herpesvirus DNA in tissues of infected fish. Journal of Fish Diseases, 25, 171-178.

Haenen, O.L.M., Way, K., Bergmann, S.M., \& Ariel, E. (2004). The emergence of koi herpesvirus and its significance to European aquaculture. Bull. Eur. Assoc. Fish Pathol., 24, 293-307.

Hedrick, R.P., Gilad, O., Yun, S., Spangenberg, J.V., Marty, G.D., Nordhausen, R.W., Kebus, M.J., Bercovier, H., \& Eldar, A. (2000). A herpesvirus associated with mass mortality of juvenile and adult koi, a strain of common carp. J. Aquat. Anim. Health, 12, 44-57.

Kanellos, T., Sylvester, I.D., D'M ello, F., Horward, C.R., Mackie, A., Dixon, P.F., Chang, K.C., Ramstad, A.,
Midlying, P.J., \& Russel, P.H. (2006). DNA vaccination can protect Cyprinus carpio against spring viremia of carp virus. Vaccine, 24, 4927-4933.

Kim, H.C., Johnson, M.C., Drennan, J.D., Simon, B.E., Thomann, E., \& Leong, Jo-Ann.C. (2000). DNA vaccines encoding viral glycoproteins induce nonspecific immunity and $\mathrm{mx}$ protein synthesis in fish. Journal of Virology, 74(15), 7048-7054.

Kobayashi, Snin-ichiro, Alimuddin., Morita, T., Miwa, M., Lu, J., Endo, M., Takeuchi, T., \& Yoshizaki, G. (2007). Transgenic nile tilapia (Oreochromis niloticus) over-expressing growth hormone show reduced ammonia excretion. Aquaculture, 270, 427-435.

LaPatra, S.E., Corbeil, S., Jones, G.J., Shewmaker, W.D., Lorenzen, N., \& Kurath, G. (2001). Protection of rainbow trout against infectious hematipoietic necrosis virus four days after specific or semispecific DNA vaccination. Vaccine, 19, 4011-4019.

Lu, Y., \& Sun, P.S. (2005). Viral resistance in shrimp that express an antisense Taura syndrome virus coat protein gene. Antiviral Res., 67, 141-146.

Maclean, N. (1998). Regulation and exploitation of transgenes in fish. Mutat Res., 399, 255-266.

Pusat Pengembangan Ikan Mas Nasional [(PPIMN]. (2012). Protokol pemuliaan ikan mas (Cyprinus carpio). Sukabumi, $44 \mathrm{hlm}$ (Unpublish).

Rakus, K.L., Wiegertjes, G.F., Adamek, M., Siwicki, A.K., Lepa, A., \& Irnazarow, I. (2009). Resistance of common carp (Cyprinus carpio L.) to Cyprinid herpesvirus-3 is influenced by major histocompatibility (MH) class II B gene polymorphism. Fish \& Shellfish Immunology, 26, 737-743.

Sano, M., Ito, T., Kurita, J., Yanai, T., Watanabe, N., Miwa, S., \& lida, T. (2004). First detection of koi herpesvirus in cultured common carp (Cyprinus carpio) in Japan. Fish Pathol., 39, 165-167.

Sano, M., Ito, T., Kurita, J., Miwa, S., \& lida, T. (2005). Diagnosis of Koi Herpesvirus (KHV) disease in Japan. Bull. Fish. Res. Agen. Supplement, 2, 59-64.

Sarmasik. A., Warr, G., \& Chen, T.T. (2002). Production of transgenic medaka with increased resistance to bacterial pathogens. Mar. Biotechnol., 4, 310-22.

Sucipto, A., Faridah, N., Mundayana, Y., Haniyanti, D., Santika, A., Mawardi, M., Handayani, D.I., Prayoga, T., Purwanto, J., Juanda, T., \& Dimyati, A. (2014). Naskah akademik ikan mas (Cyprinus carpio) Majalaya tahan penyakit. Balai Besar Perikanan Budidaya Air Tawar. Sukabumi, $38 \mathrm{hlm}$ (Unpublish).

Sunarto, A., Rukyani, A., \& Itami, T. (2005). Indonesian experience on the outbreak of Koi Herpes Virus in koi and carp (Cyprinus carpio). Bull. Fish. Res. Agen. Supplement, 2, 15-21. 
Syahputra, K., Himawan, Y., \& Ariyanto, D. (2014). Evaluasi ketahanan ikan mas (Cyprinus carpio) transgenik yang membawa gen glikoprotein terhadap Koi Herpesvirus (KHV). Dalam Sugama, K., Kusnendar, E., Rachmansyah, Giri, N.A., Yuhana, M., Kristanto, A.H., Imron, Radiarta, I N., \& Dewi, R.R.S.P.S (Eds.). Prosiding Forum Inovasi Teknologi Akuakultur. Pusat Penelitian dan Pengembangan Perikanan Budidaya. Jakarta, hlm. 1075-1081.

Weifeng, M., Yaping, W., Wenbo, W., Bo, W., Jianxin, F., \& Zuoyan, Z. (2004). Enhanced resistance to Aeromonas hydrophila infection and enhanced phagocytic activities in human lactoferrin-transgenic grass carp (Ctenopharyngodon idellus). Aquaculture, 242, 93-103.

Zhong, J., Wang, Y., \& Zhu, Z. (2002). Introduction of the human lactoferrin gene into grass carp (Ctenopharyngodon idellus) to increase resistance against GCH virus. Aquaculture, 214, 93-101.

Zhong, C., Song, Y., Wang, Y., Li, Y., Liao, L., Xie, S., Zhu, Z., \& Hu, W. (2012). Growth hormone transgene effects on growth performance are inconsistent among offspring derived from different homozygous transgenic common carp (Cyprinus carpio). Aquaculture, 356-357, 404-411. 